\title{
AGRI-PRODUCT EVALUATION AND BIODIVERSITY MEASUREMENT
}

\author{
Szilvia Kovács \\ University of Debrecen, Faculty of Agriculture, Hungary, H-4032 Debrecen, Böszörményi út 138.
}

\begin{abstract}
This paper is meant to be the first part of a two part unit that will be published next. The objective of this paper is to be an introduction of agri-product evaluation, within which a short summary of essentials of diversity measurement is given and to share experience on evaluation of environmental friendly agri-product. For biodiversity measurement and extern effects, literature of related publications was processed and experience gained over experimental projects on environmental-friendly technologies was summed up. Methods applied were based on influence-response approach which guided us all through the research work.

It can be stated that one diversity measure or one diversity function fails to describe communities of living beings; therefore, at least two methods should be used in parallel. Scale-dependent description of diversity is necessary, which provides us with new information that can not be revealed by traditional methods. To identify external effects, we have to take influences of use of a specific product into account and the responses generated by use of that product. Influences might appear in parallel or can build up one another, similarly to the generated responses of environment. To be as precise as possible, it is suggested that we take into account only clear responses. Influence-response relations are shown here using terms and concepts in broad sense and in general. More sophisticated application of terms and concepts is needed to evaluate properly and in monetary terms. We will make efforts to clarify terms and their use in the future.
\end{abstract}

Key words: biodiversity measurement, agri-product, external effects, influence-response

\section{Introduction}

External effects of any product or applied technology stemming from operations intervening ecosystems have been getting more in focus, but they are far not stressed upon. A lot of troubles have been identified so far which are very difficult to handle. A well known trouble is the wetlands in danger all over the world (Kerekes et al., 1994; Kerekes and Szlávik, 1999). Biodiversity is a real challenge to measure, since it is very difficult to look into, being so complex and dynamic. Nowadays expressing the value of biodiversity is also calculated in monetary unit, but it also demands efforts because of value factors independent of use. There are tools developed and used, but they differ in applicability. Evaluation of such tools by Pearce et al. (1999) is available in order to embed them in practice. At the same time evaluation of agri-products has not embedded properly in practice, but some reports related to the theme are available (Felföldi, 2008a; 2008b).

This paper is meant to be the first part of a two part unit that will be published next. The objective of this paper is to be an introduction of agri-product evaluation, within which a short summary of essentials of diversity measurement is given and to share experience on evaluation of environmental friendly agri-product.

\section{Material and method}

Influencing biodiversity as an external effect might be a characteristic of any product or intervention, which is highly true for a production technology. For biodiversity measurement and extern effects, literature of related publications was processed and experience gained over experimental projects on environmental-friendly technologies was summed up. We processed relevant data of two experimental projects such as environmental friendly soil cultivation and its effects on diversity of weed communities, and usage of mixture of seeds as multifunctional agri-product. The first is technology centered, focusing on effects on diversity of weeds by variants of soil cultivation as an operation within the technological process of crop production. The second is focusing on the use of an agri-product that is a final product meant to be applied e.g. in game management. To evaluate the effects of this final product of agricultural origin we applied influence-response approach which guided us all through the research work. There were two experimental spots with relatively small-sized plots for mixtures differing in ingredients of seed. Vegetations of different mixtures were left on the spot for all year round. Year round monitoring provided us with data to be processed from many aspects, covering biodiversity, too.

Experience on diversity measurement and the place of diversity as field from which responses can be identified are presented in chapter 3.1. and 3.2., respectively. 


\section{Results and discussion}

\subsection{Diversity measurement}

Researchers noted that there was need to work out measures and functions in order to make comparisons between species, taxons, ecological systems etc. Total number of species (ST) as a diversity measure is to determine the pool of species. This measure fails to reflect status of mass, furthermore, this does not allow us to compare communities. The methods besides the components take into account status of mass and structure of dominance. These methods use such measures as those of which rise when being an increase in the number of species, as well as being more even distribution of status of mass.

There are texture examinations based on distribution and not based on distribution. These latter ones are called diversity indices (Whittaker, 1972,). Methods based on distribution could represent textural relations but failed to give structural relationship. Diversities not based on distributions concern abundance $(\mathrm{N})$ in the sample. Disadvantage of ST/N ratio is the low value we often get and that non-linearity which often occurs between number of species and abundance. Therefore, Gleason (1922) and Menhinick (1964) advise to use $\mathrm{S} / \log \mathrm{N}$ and $\mathrm{S} / \mathrm{VN}$, respectively.

Table 1. Basic statistics of diversity for variants of tillage (summer time)

\begin{tabular}{|l|c|c|c|c|}
\hline SUMMER & $\begin{array}{c}\text { Direct } \\
\text { drilling }\end{array}$ & $\begin{array}{c}\text { Field } \\
\text { ploughed } \\
\text { by disk- } \\
\text { ripper }\end{array}$ & $\begin{array}{c}\text { Shallow } \\
\text { ploughed } \\
\text { field }\end{array}$ & $\begin{array}{c}\text { Traditional } \\
\text { tillage }\end{array}$ \\
\hline Species Total (ST) & 22,0 & 9,0 & 15,0 & 10,0 \\
\hline Average species $\left(\mathbf{S}_{\text {aver }}\right.$ ) & 8,4 & 4,6 & 6,0 & 2,8 \\
\hline Median of species & 7,0 & 4,0 & 7,0 & 2,0 \\
\hline $\begin{array}{l}\text { Number of individual } \\
\text { plants (N) }\end{array}$ & 191,0 & 179,0 & 197,0 & 157,0 \\
\hline $\begin{array}{l}\text { Average number of } \\
\text { individual plants }\left(\mathbf{N}_{\text {aver }} \text { ) }\right.\end{array}$ & 38,2 & 35,8 & 39,4 & 31,4 \\
\hline ST/N & 0,115 & 0,050 & 0,076 & 0,063 \\
\hline
\end{tabular}

Note: figures in the table only as examples here

There are some often used diversity measures and basic statistics in table 1. Figures belong to 3 variants of an environmental friendly operation and the control operation, being here as an example only. It is the number of species that naturally refers to diversity. The total number of species informs on total of species on research area. If it is the ST/N ratio that we use to measure diversity, then we might get different result in ranking diversity.

The next group of diversity measurement is represented by classical diversity functions (table 2.) that are based on abundance- dominance structure of a community. Thus, it is taken into account how many individuals of a genus exist in the community. They are common in ordering functions rareness /R(i;p)/ to genus i. of the (S;p) community (Patil and Taillie, 1979).

Classical diversity functions reasonable to use are Shannon-diversity sensible to rare species, Simpson diversity and Berger-Parker diversity sensible to dominant species.
Table 2. Classical diversity functions for variants of tillage (summer time)

\begin{tabular}{|l|c|c|c|c|}
\hline SUMMER & $\begin{array}{c}\text { Direct } \\
\text { drilling }\end{array}$ & $\begin{array}{c}\text { Field } \\
\text { ploughed } \\
\text { by disk- } \\
\text { ripper }\end{array}$ & $\begin{array}{c}\text { Shallow } \\
\text { ploughed } \\
\text { field }\end{array}$ & $\begin{array}{c}\text { Traditional } \\
\text { tillage }\end{array}$ \\
\hline Shannon diversity (HS) & 2,5836 & 1,7153 & 2,3219 & 1,9476 \\
\hline Evenness & 0,8358 & 0,7807 & 0,8574 & 0,8458 \\
\hline Simpson diversity (DQ) & 0,8906 & 0,7791 & 0,8786 & 0,8267 \\
\hline Evenness & 0,9330 & 0,8765 & 0,9413 & 0,9186 \\
\hline $\begin{array}{l}\text { Diversity by } \\
\text { Berger-Parker }\end{array}$ & 4,0445 & 3,0675 & 4,4204 & 3,4602 \\
\hline
\end{tabular}

Note: figures in the table only as examples here

Tóthmérész (1997) stated that examining the same community with using different diversity functions could result in contradictions. Solving the contradiction, Alfréd Rényi (1961) published the generalisation of Shannon-function which was followed by a study by Patill and Taillie (1979). They suggested that diversity profiles should be used to describe diversity and to compare communities. In case the profiles of communities to be compared with do not cross, the communities can be ordered by diversity and the one is more diverse, which has the profile running higher. If the curves do not cross, then the communities cannot be ordered by diversity. This is because one community is more diverse for rare species than the other, and opposite is the case for dominant species. The -ordered entropy by Renyi (Figure 1.) is only one of the one-parametric diversity functions that are discussed by Tóthmérész (1997).

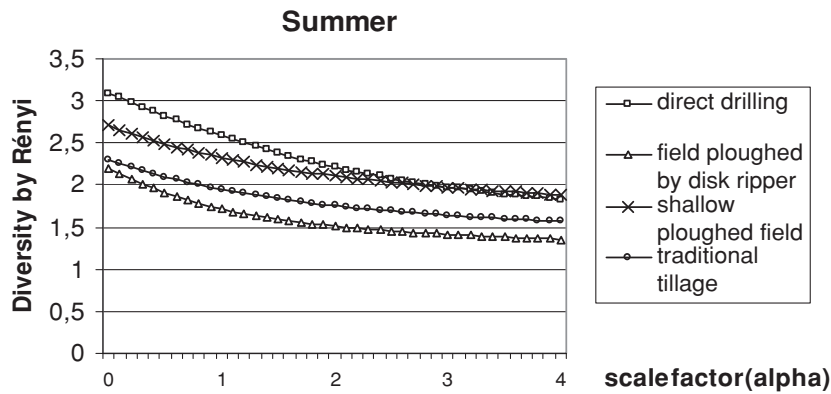

Figure 1. Diversity ranking by Rényi of variants of tillage (summer) Note: figures in the table only as examples here

Our experience assists the suggestion that a community should be examined by more functions in parallel in order to avoid failures. If these diversity functions result in doubtful ranking, therefore, it is reasonable to do diversity ordering.

\subsection{External effects}

External effects of agricultural origin can be generated by mainly two ways. One is production of food and non-food produce, and the other one is doing activities with purpose of agro-environmental protection. For food and non-food production, external effects are generated as indirect (connected) outputs. For activities with special purpose of environmental protection they are direct outputs, which are mainly common goods, so is the biodiversity, too. 
Table 3. Influence-response relations

\begin{tabular}{|c|c|c|c|c|c|c|c|c|c|}
\hline \multirow[b]{2}{*}{ Influence } & \multicolumn{9}{|c|}{ Response } \\
\hline & scene & $\begin{array}{l}\text { soil- } \\
\text { life }\end{array}$ & air & $\begin{array}{c}\text { bio- } \\
\text { diversity }\end{array}$ & $\begin{array}{c}\text { wild } \\
\text { life } \\
\text { dynamics }\end{array}$ & harm & tourism & $\begin{array}{c}\text { agric. } \\
\text { produc- } \\
\text { tion }\end{array}$ & $\begin{array}{c}\text { human } \\
\text { environ- } \\
\text { ment }\end{array}$ \\
\hline $\begin{array}{l}\text { More diverse } \\
\text { environment }\end{array}$ & + & + & + & & + & & + & & + \\
\hline Life-place & & & & + & + & + & + & & \\
\hline Shelter & & & & + & + & & + & & \\
\hline Source of feed & & & & + & + & & & & \\
\hline $\begin{array}{l}\text { Arable land } \\
\text { reserved }\end{array}$ & & & & & & & & - & \\
\hline
\end{tabular}

Source: Felföldi, 2008a

To identify external effects, we have to take influences of use of a specific product and the generated responses by use of that product. In our case the product is an agri-product as input for non-food activity. To express external effect in monetary term, the beginning step is to be aware of the influenceresponse relations. Influences might appear in parallel or can build up one another, similarly to the generated responses of environment. To be as precise as possible, it is suggested that we take into account only clear responses (Felföldi, 2008a). The use of an agri-product can be described by influence-response relations in general from aspects of external effects. A specific agri-product is described from this aspect in Table 3.

The influence-response relations shown here is to present the fields from which responses can derive, but we used terms and concepts in broad sense and in general. More sophisticated application of terms and concepts is needed to evaluate properly and in monetary terms.

For the agri-product examined, we found more diverse environment, life-place, shelter, and source of feed for wild life, and field reserved as main influences. The latter one refers to croplands tied up instead of production such as for example the set-aside.

As responses we found more scenic environment, richer and better soil-life and air, and more diverse life. At the same time, wild life dynamics can get better, but harms caused by the wild can decrease. More scenic environment, diverse wild life and better wild life dynamics - including game dynamics - will attract tourists, furthermore, travellers and people during activities of recreation will be happy with them too, considering game in abundance e.g.. They can generate good feeling and better atmosphere among people, which can be considered as better human environment.

Lands used for application of these agro-products will decrease agricultural production, whatever food or non-food production they are. It might not be considered to be a reasonable decision from profit oriented view.

\section{Conclusions}

Diversity profiles should be used to describe diversity and to compare communities. It is established that using only one diversity measure or one diversity function fails to describe communities of the living beings, therefore at least two methods should be used in parallel. Scale-dependent description of diversity is necessary, which provides us with new information that can not be revealed by traditional methods. Classical diversity functions reasonable to use are Shannondiversity sensible to rare species, Simpson diversity and Berger-Parker diversity sensible to dominant species. If these diversity functions result in doubtful ranking, it is reasonable to do diversity ordering.

To identify external effects, we have to take influences of use of a specific product and the generated responses by the use of the product. Since influences might appear in parallel or can build up one another, similarly to the generated responses of environment, it is suggested that we take into account only clear responses.

Influence-response relations are shown here using terms and concepts in broad sense and in general. More sophisticated application of terms and concepts is needed to evaluate properly and in monetary terms. We will make efforts to clarify terms and their use in the future.

\section{References}

1. Gleason, H.A. (1922): On the relation between species and area. Ecology 3. pp.156-162.

2. Felföldi J. (2008a): External effect examination In: Szúcs I. (ed.): Development of agri-product to conserve biodiversity. EA_KUTF_05-BIODIVER, Interim report, 2008

3. Felföldi J. (2008b): Adaptation into AKG. In: Szücs I. (ed.): Development of agri-product to conserve biodiversity. EA_KUTF_05-BIODIVER, Interim report, 2008

4. Kerekes, S. - Kindler, J.- Csutora, M. - Koloszár, M.- Péter, S. - Zsolnai, L.(1994): Economic evaluation of the GabcikovoNagymaros Project, Centre for Environmental Studies, Budapest, November.

5. Kerekes, S. - Szlávik J. (1999): A környezeti menedzsment közgazdasági eszközei. KJK, Budapest. Második kiadás.

6. Menhinick, E.F.(1964): A comparison of some species-individuals diversity indices applied to samples of field insects. Ecology 45, pp. 859-861.

7. Patil, G.P. and Taillie, C. (1979): An overview of diversity..In: Grassle-Patil-Smith-Taillie: Ecological diversity in theory and practice. pp. 3-27. International Cooperative Publishing House, Fairland, Maryland.

8. Pearce, D. - Moran, D. - Krug, W. (1999): The global value of biological diversity. Final report to UNEP. CSERGE, London, September

9. Rényi, A. (1961): On measure of entropy and information. Proceedings of the 4th Berkeley Symposium on mathematical statistic and probability (vol 1.) pp. 547-561. University of California Press, Berkeley.

10. Tóthmérész, B. (1997): Diverzitási rendezések. Scientia Kiadó, Budapest.

11. Whittaker, R.H.(1972): Evolution and measurement of species diversity. Taxon 21:pp 213-251. 